\title{
Changes in Benthic Macrofauna Associated with a Shallow-Water Hydrothermal Vent Gradient in Papua New Guinea ${ }^{1}$
}

\author{
David 7. Karlen, ${ }^{2}$ Roy E. Price, ${ }^{3,4}$ Thomas Pichler, ${ }^{3,4}$ and Fames R. Garey ${ }^{2,5}$
}

\begin{abstract}
Infaunal macroinvertebrates were characterized along an environmental gradient from a shallow-water hydrothermal vent located at Tutum Bay, Ambitle Island, Papua New Guinea. Samples were collected at three sites located at 7.5, 60, and $150 \mathrm{~m}$ from the vent and from a nonhydrothermal reference site located to the north. Temperature and arsenic concentration were found to decrease and $\mathrm{pH}$ increased with distance away from the vent. At each site, five replicate core samples were taken randomly from a $1 \mathrm{~m}^{2}$ sampling grid. All infaunal invertebrates $>500 \mu \mathrm{m}$ were sorted, identified to the lowest practical taxonomic level and counted. Results from the macrofauna data show a strong trend of increasing abundance, species richness and diversity relative to distance away from the vent, but even at $150 \mathrm{~m}$ the benthic macrofauna appeared to be depressed relative to the reference site. Mollusks were completely absent $7.5 \mathrm{~m}$ from the vent, rare at $60 \mathrm{~m}$, and abundant at $150 \mathrm{~m}$, suggesting that the low $\mathrm{pH}$ values associated with the hydrothermal activity play an important role in the benthic community structure.
\end{abstract}

Shallow-water hydrothermal vents occur worldwide, but relatively few studies have been carried out on the benthic community structure of these systems (Thiermann et al. 1997). Several such systems that have been studied in some detail include sites in the Mediterranean and Aegean seas (Thiermann et al. 1997, Gamenick et al. 1998, Morri et al. 1999, Cocito et al. 2000), the Kurile Islands (Tarasov et al. 1990, Sorokin et al. 2003, Kamenev et al. 2004), New Zealand (Kamenev

\footnotetext{
${ }^{1}$ Funding provided by a National Science Foundation Biocomplexity grant (BE/CBC 0221834). Manuscript accepted 9 September 2009.

${ }^{2}$ Department of Cell Biology, Microbiology, and Molecular Biology, University of South Florida, 4202 East Fowler Avenue, BSF218, Tampa, Florida 33620.

${ }^{3}$ Department of Geology, University of South Florida, 4202 East Fowler Avenue, SCA528, Tampa, Florida 33620.

${ }^{4}$ Current affiliation: MARUM Center for Marine and Environmental Research, University of Bremen, Bremen, Germany.

${ }^{5}$ Corresponding author (e-mail: garey@usf.edu).
}

Pacific Science (2010), vol. 64, no. 3:391-404 doi: $10.2984 / 64.3 .391$

(C) 2010 by University of Hawai'i Press

All rights reserved et al. 1993), the Gulf of California and southern California (Melwani and Kim 2008), and several sites in Papua New Guinea including Rabaul harbor (Tarasov et al. 1999) and Ambitle Island (Pichler and Dix 1996, Pichler and Veizer 1999, Pichler et al. 1999a,b). The last site was the focus of the current study.

Previous work carried out on Ambitle Island focused on the geochemistry of the hydrothermal fluids and surrounding sediment. Vent and pore waters were enriched in several elements, but, most notably, arsenic concentrations were 275 times that of normal seawater (Pichler et al. 1999b). Despite the elevated concentration of arsenic, the surrounding reef habitat and fauna appear to be unaffected (Pichler and Dix 1996). This is likely due to the removal of arsenic from the water column via the precipitation of Fe (III) oxyhydroxides (Pichler and Veizer 1999, Pichler et al. 1999a). Because of that previous work, we focused this study on the influence of arsenic, along with other vent-related factors such as temperature, $\mathrm{pH}$, and sediment characteristics, on the benthic macrofauna near the Ambitle Island vent.

Arsenic is naturally occurring in Ambitle Island groundwater, which is the source of the hydrothermal fluids at these vents (Pich- 
ler et al. 1999b). Elemental arsenic is commonly found in two inorganic forms: arsenate [As (V)] and arsenite [As (III)] (Francesconi and Kuehnelt 2002, Oremland and Stolz 2003, Watt and Le 2003). These compounds can be metabolized by several prokaryotes through either the respiration of arsenate or the oxidation of arsenite, particularly in extreme environments (Inskeep et al. 2002, Oremland and Stolz 2003, Oremland et al. 2005). In addition, eukaryotic organisms can convert inorganic arsenic into organic compounds via methylation (Andreae 1979, Kitts et al. 1994, Cutter et al. 2001), and there is some evidence that these can be transferred among different trophic levels (Barwick and Maher 2003).

Pore water $\mathrm{pH}$ is an important variable in geochemical processes. Previous studies at the Ambitle Island vents found reduced $\mathrm{pH}$ levels in the vent fluids that were attributed to high levels of $\mathrm{CO}_{2}$ in the fluids and gas bubbles discharging from the vents (Pichler et al. 1999b). In addition, low $\mathrm{pH}$ can influence sediment composition by the dissolution of carbonate sediments (Burdige and Zimmerman 2002) and impair carbonate incorporation in shell-bearing organisms (Green et al. 1993). Acidification of seawater associated with release of $\mathrm{CO}_{2}$ at shallow-water vents has been observed off of Italy by HallSpencer et al. (2008). In their study they reported reduced densities of calcareous algae and invertebrates at sites with reduced $\mathrm{pH}$ and observed signs of shell dissolution on gastropods (Hall-Spencer et al. 2008).

Initial field observations at the study site indicated a distinctive gradation in the sediment composition in relation to the measured offshore distance from the vent. The relationship between sediment characteristics (grain size, organic carbon content) and the benthic infaunal community has long been recognized (Sanders 1958). The interrelationships of sediment properties and benthic communities are complex (Snelgrove and Butman 1994), but, in general, fine-grained sediments and high organic carbon content tend to be dominated by deposit feeders, and coarse sediments tend to support more suspensionfeeding organisms.
Field observations also indicated that carbonate content of sediment was lower nearer the vent, with carbonates increasing with distance from the vent. Near shore and in the vicinity of the vents the sediments were predominately fine-grained volcanic sands, with some gravel-sized deposits near the vent. A gradual mixture of biogenic carbonates was observed starting around $100 \mathrm{~m}$ from the vent, consisting of fragments of calcareous algae and coral rubble from the surrounding reef. Bioturbation by burrowing organisms can further affect grain size and carbonate content of the sediment (Aller 1982).

The primary goal of this study was to investigate the effect of a natural hydrothermal gradient on the benthic macrofauna. To do this, we measured pore water and sediment arsenic concentrations, temperature, $\mathrm{pH}$, and sediment composition and characterized the benthic fauna at different distances from a shallow hydrothermal vent. It was expected that elevated arsenic concentrations would be a primary factor in structuring the benthic community. Studies of similar systems focused on depth rather than distance from the shallow vents (Tarasov et al. 1999), sampled at only select sites (Kamenev et al. 1993), or sampled short transects of $5 \mathrm{~m}$ (Thiermann et al. 1997). This study is unique because sampling was carried out over a $150 \mathrm{~m}$ transect, and hydrothermal effects were found even at that distance.

\section{MATERIALS AND METHODS}

The study site was located in Tutum Bay, Ambitle Island, Papua New Guinea ( $4^{\circ} 05^{\prime} \mathrm{S}$ latitude, $153^{\circ} 40^{\prime} \mathrm{W}$ longitude) (Figure 1). The island is an active volcano, with several large hot springs on shore in addition to the submarine hydrothermal vents. The hydrothermal vents in this study were located at a water depth of $10 \mathrm{~m}$ and were surrounded by an extensive coral reef system with intermittent patches of sand. The main vent had a focused discharge of 300-400 liters/min hydrothermal fluids through a narrow, $15 \mathrm{~cm}$ diameter opening in the seafloor (Pichler et al. 1999b). In the sandy areas immediately surrounding the vent, a diffuse discharge of hy- 

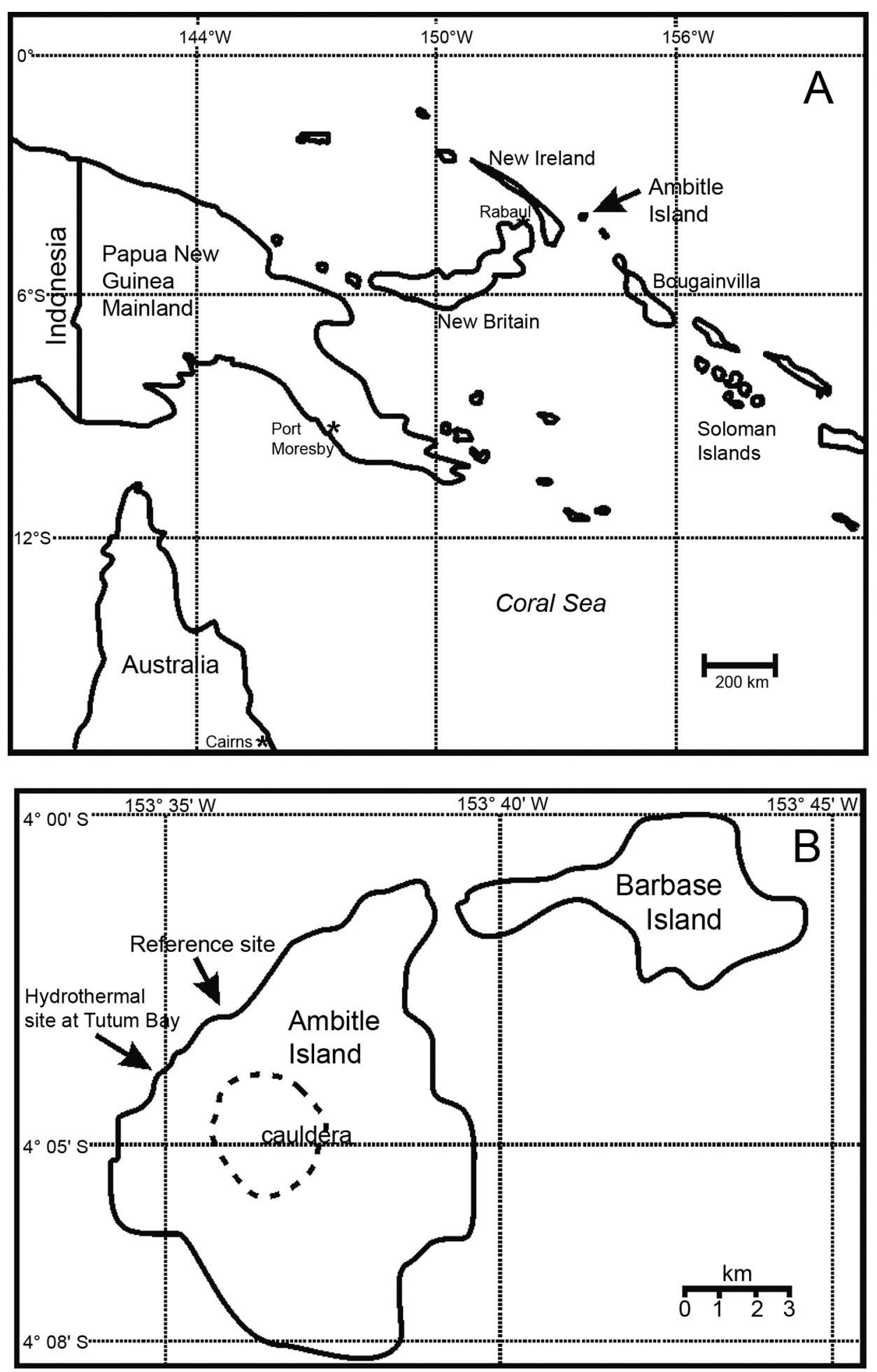

Figure 1. (A) Map of Papua New Guinea and its geographic relation to Australia. Ambitle Island is marked with an arrow and is located east of New Ireland. Latitude and longitude are marked in degrees. $(B)$ Map of Ambitle Island with the study sites marked with arrows. Latitude and longitude are indicated in degrees and minutes. 


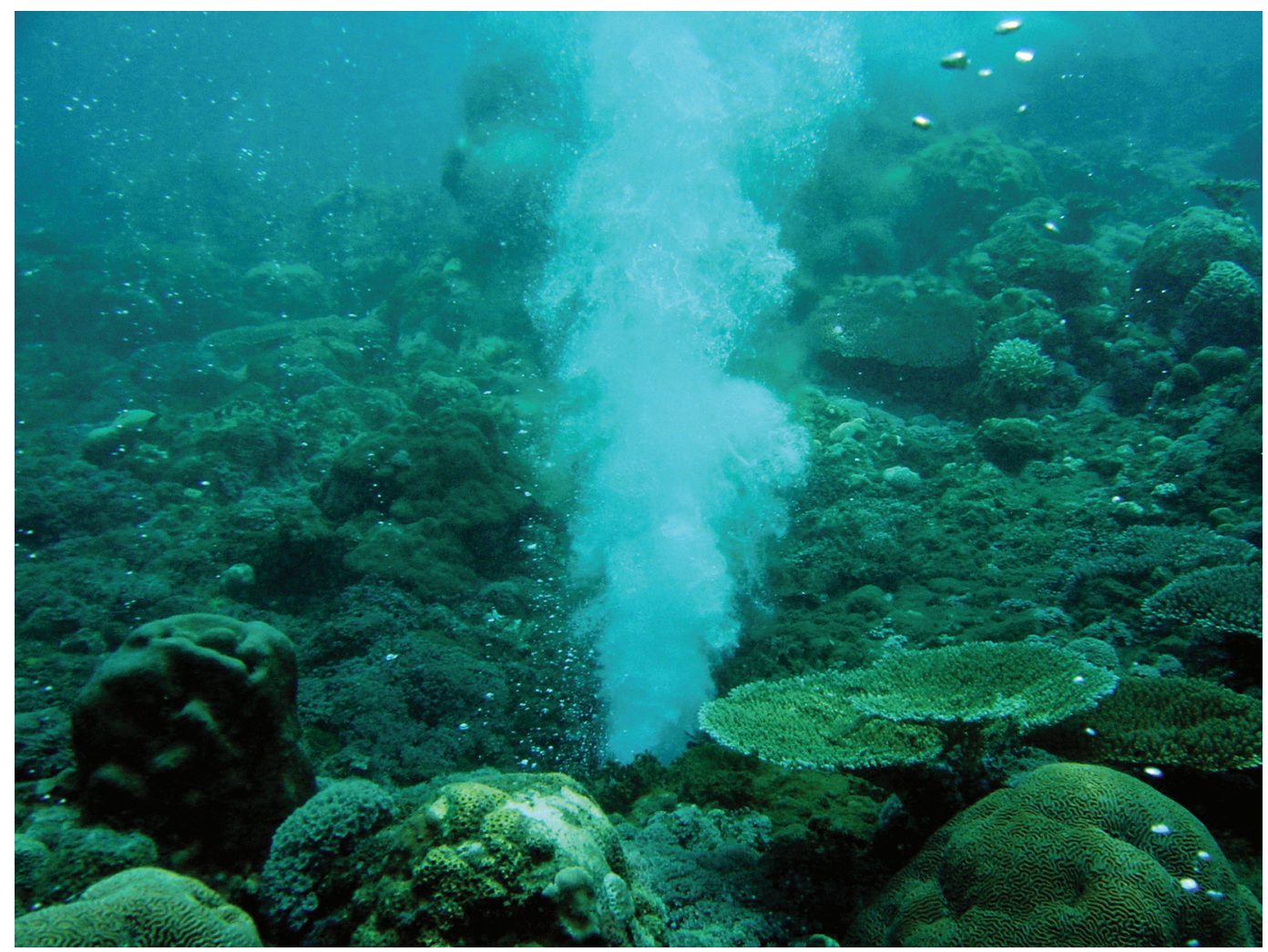

Figure 2. Photograph of focused hydrothermal vent at Tutum Bay, Ambitle Island, Papua New Guinea, with surrounding diffuse venting. (Photo credit: D.J.K.)

drothermal fluids and gases was observed as a steady stream of bubbles rising from the sediment. This diffuse venting was strongest near the main vent but appeared sporadically as far as $60 \mathrm{~m}$ away (Figure 2).

Benthic macrofauna samples were collected at three sites along a transect running from a focused hydrothermal discharge. The transect ran southwest from the vent along a sandy bottom for $30 \mathrm{~m}$ and then continued offshore to the west to avoid the reef. The maximum depth along the transect was $15 \mathrm{~m}$. Sample sites were at $7.5,60$, and $150 \mathrm{~m}$ along the transect line, representing a subset of sites chosen for geochemical analysis. These sites were selected based on sediment temperature profiles conducted along the transect that indicated that each site would represent a decreasing trend in the hydrothermal influence with distance from the vent, with the $150 \mathrm{~m}$ site presumably outside the hydrothermal zone. Additional samples were collected at a single reference site located approximately $1.6 \mathrm{~km}$ north of Tutum Bay in an area not affected by hydrothermal activity and at a depth similar to that of the transect sites. Sampling was limited by logistical problems encountered in shipping supplies to the site and in shipping samples back to the laboratory in the United States. At each site along the transect a $1 \mathrm{~m}^{2}$ grid was placed next to the transect line. A single grid was sampled at the reference site. The grid was subdivided into 10010 by $10 \mathrm{~cm}$ cells, and five cells were selected for sampling using a random number table (Rohlf and Sokal 1981). Five core samples $\left(\right.$ diameter $=7.62 \mathrm{~cm}$; area $\left.=45.6 \mathrm{~cm}^{2}\right)$ were taken from random grid cells within the $1 \mathrm{~m}^{2}$ quadrat to a depth of $15 \mathrm{~cm}$. The core samples were sieved through a $500 \mu \mathrm{m}$ mesh sieve, and the retained animals were fixed in $10 \%$ formalin with Rose Bengal stain 
for a minimum of $72 \mathrm{hr}$ and then transferred into $70 \%$ methanol for preservation. Organisms were sorted from the sediment under a dissecting microscope, identified to the lowest practical taxonomic level, and enumerated.

Three smaller cores (diameter $=3.0 \mathrm{~cm}$ ) were taken at randomly selected grid cells for sediment grain size and organic carbon and carbonate content analysis at each site. The sediment samples $(50 \mathrm{~g})$ were dry sieved through a stacked series of sieves and divided into six Wentworth Size Classes (Percival and Lindsay 1997): Gravel $(>2,000 \mu \mathrm{m})$, Coarse Sand $(>500 \mu \mathrm{m})$, Medium Sand $(>250 \mu \mathrm{m})$, Fine Sand $(>125 \mu \mathrm{m})$, Very Fine Sand $(>63$ $\mu \mathrm{m})$, Silt + Clay $(<63 \mu \mathrm{m})$. The organic content of the sediment was determined by loss on ignition (LOI) from $2 \mathrm{~g}$ of sample at $550^{\circ} \mathrm{C}$ for $4 \mathrm{hr}$, and sediment carbonate content was calculated after additional LOI at $950^{\circ} \mathrm{C}$ for $2 \mathrm{hr}$ following Heiri et al. (2001). Methods used for the field measurements of temperature and $\mathrm{pH}$ and the collection and analysis of pore water and sediment chemistry samples are described in Price and Pichler (2005). Pore water measurements were taken at a depth of $10 \mathrm{~cm}$ except where noted in Table 1. Sediment arsenic content indicated in Table 2 is from surface sediment samples.

Parametric statistical analysis was conducted using SigmaStat 3.5 (Systat Software 2005). One-way analysis of variance (ANOVA) with a Holm-Sidak multiple comparison procedure test was used to test for between-site differences in sediment characteristics and benthic community metrics (species richness, abundance, diversity). A nonparametric Kruskal-Wallis ANOVA on ranks was used to test for the presence of between-site differences in the Pielou's Evenness index because index values failed normality testing. All other metrics passed for normality without data transformations. Sediment grain size and organic carbon and carbonate content data were arcsine transformed for normality before analysis. Between-site statistical testing for the pore water temperature, $\mathrm{pH}$, and sediment/pore water arsenic concentrations was not performed because only one measurement or sample was collected per site. Basic community indices (species richness, abundance,
Shannon-Weaver Diversity, and Pielou's Evenness) and multivariate analysis were done using PRIMER v. 6 (Clarke and Gorley 2006). The Bray-Curtis Similarity index was calculated on square root transformed abundance data to measure the similarity of the benthic species composition among replicates within a site and between sites. Analysis of similarity (ANOSIM) was used to test for differences in the species composition between sites, and the similarity percentage (SIMPER) procedure was used to determine which taxa contributed to the within-site similarity or between-site differences. The BIO-ENV analysis procedure in PRIMER v. 6 was used to calculate Spearman ranked correlations between the physical/sediment measurements and the benthic macrofauna composition. All physical/sediment data were log transformed and normalized before analysis.

The BIO-ENV procedure compares the underlying similarity/distance matrices for the biological and physical data to find the combination of physical variables that best explains the ordination pattern among the samples based on their species similarity (Clarke and Ainsworth 1993). This method has several advantages in that it incorporates the full range of biotic and physical data collected and is not dependent on a normal distribution of the data because it utilizes rankbased correlations.

\section{RESULTS}

There were observed differences between sites for all physical parameters (Table 1). Temperature showed the highest value at 7.5

\section{TABLE 1}

Summary of Pore Water Characteristics at Tutum Bay, Ambitle Island, Papua New Guinea, November 2003

\begin{tabular}{lccc}
\hline \hline Distance $(\mathrm{m})$ & Temp. $\left({ }^{\circ} \mathrm{C}\right)$ & $\mathrm{pH}$ & {$[$ As] $(\mu \mathrm{g} / \mathrm{liter})$} \\
\hline 7.5 & 45.5 & 6.2 & $81^{*}$ \\
60.0 & 33.3 & 6.8 & 16 \\
150.0 & 31.0 & 7.2 & 63 \\
REF & $30.2^{*}$ & 7.6 & 3.3 \\
\hline
\end{tabular}

Note: All pore water measurements are from Price and Pichler (2005) and represent values measured at a depth of $10 \mathrm{~cm} \mathrm{ex-}$ cept $^{*}=0 \mathrm{~cm}$. 
TABLE 2

Sediment Grain Size Class Percentages, Percentage Organic Carbon and Carbonates (Mean \pm 1 Standard Deviation) (Arsenic Concentrations from Price and Pichler [2005])

\begin{tabular}{lccrr}
\hline \hline Wentworth Size Class & $7.5 \mathrm{~m}$ & $60 \mathrm{~m}$ & $150 \mathrm{~m}$ & \multicolumn{1}{c}{ REF } \\
\hline Gravel & $32.99 \pm 10.39$ & $0.17 \pm 0.06$ & $0.92 \pm 0.22$ & $24.83 \pm 10.26$ \\
Coarse Sand & $0.71 \pm 0.33$ & $0.23 \pm 0.17$ & $0.19 \pm 0.02$ & $1.32 \pm 0.14$ \\
Medium Sand & $4.38 \pm 2.27$ & $4.30 \pm 0.32$ & $17.87 \pm 2.14$ & $36.24 \pm 0.08$ \\
Fine Sand & $7.36 \pm 1.53$ & $3.50 \pm 0.43$ & $36.15 \pm 1.32$ & $12.54 \pm 2.25$ \\
Very Fine Sand & $53.10 \pm 8.61$ & $89.60 \pm 1.15$ & $42.58 \pm 1.04$ & $18.10 \pm 5.76$ \\
Silt + Clay & $1.46 \pm 0.11$ & $2.20 \pm 1.18$ & $2.30 \pm 0.68$ & $6.97 \pm 2.61$ \\
\% organic carbon & $1.66 \pm 0.08$ & $1.33 \pm 0.29$ & $3.57 \pm 0.43$ & $7.59 \pm 1.04$ \\
\% carbonates & $0.51 \pm 0.11$ & $0.29 \pm 0.18$ & $3.75 \pm 0.63$ & $50.37 \pm 0.99$ \\
{$[$ As] (ppm) } & 783 & 614 & 402 & 2.2 \\
\hline
\end{tabular}

TABLE 3

Benthic Community Index Values Cumulated for All Five Replicate Samples at Each Site

\begin{tabular}{lcccc}
\hline \hline Distance $(\mathrm{m})$ & Number of Taxa $(S)$ & Abundance $(N)$ & Diversity $\left(H^{\prime}\right)$ & Evenness $\left(\mathcal{f}^{\prime}\right)$ \\
\hline 7.5 & 6 & 14 & 1.48 & 0.82 \\
& $(2 \pm 0.71)$ & $(2.8 \pm 1.3)$ & $(0.59 \pm 0.38)$ & $(0.92 \pm 0.08)$ \\
60.0 & 20 & $(7.8 \pm 5.4)$ & $(1.60 \pm 0.36)$ & $(0.98 \pm 0.94$ \\
& $(5.8 \pm 3.03)$ & 111 & 3.71 & 0.92 \\
150.0 & 55 & $(22.2 \pm 7.69)$ & $(2.73 \pm 0.21)$ & $(0.97 \pm 0.02)$ \\
& $(17 \pm 3.87)$ & 201 & 4.50 & 0.95 \\
$\mathrm{REF}$ & 116 & $(40.2 \pm 10.92)$ & $(3.32 \pm 0.25)$ & $(0.97 \pm 0.01)$ \\
& $(31.6 \pm 7.64)$ & & & \\
\hline
\end{tabular}

Note: Mean values \pm 1 standard deviation are shown in parentheses. Abundance $(N)$ expressed as count per sample; sample area $=0.00456 \mathrm{~m}^{2}$.

$\mathrm{m}$ but had decreased to near ambient levels at $60 \mathrm{~m}$. The $\mathrm{pH}$ was lowest at $7.5 \mathrm{~m}$ and increased with distance from the vent. Pore water arsenic was highest near the vent, decreased substantially at $60 \mathrm{~m}$, and increased again at $150 \mathrm{~m}$. All three transect sites had greatly elevated arsenic concentrations relative to the reference site.

Sediment characteristics also exhibited differences between sites along the transect and relative to the reference site (Table 2). The sediment at $7.5 \mathrm{~m}$ was predominantly gravel and very fine sands with low organic carbon and carbonates. The $60 \mathrm{~m}$ site was dominated by very fine sands low in organic carbon and carbonate. The $150 \mathrm{~m}$ site was also predominately very fine sand but had a greater proportion of medium- and fine-sized sediments. The reference site had a high percentage of gravel largely composed of coral rubble, as well as a large amount of medium sands. There was a significant difference in the percentage organic carbon between sites $(F=95.5 ; \mathrm{df}=3,8 ; P<.001)$, with the 150 $\mathrm{m}$ site having higher values than the 7.5 and $60 \mathrm{~m}$ sites and the reference site having higher values than all three transect sites. The percentage carbonates were also significantly higher at the reference site $(F=2011$; $\mathrm{df}=3,8 ; P<.001)$. Total arsenic in the surface sediments exhibited a decreasing trend along the transect away from the vent, but values at all three transect sites were higher than at the reference site.

Both the number of taxa $(S)$ and overall abundance $(N)$ increased with distance away from the vent (Table 3), and all transect sites were significantly lower than the reference site for both measures (Figure $3 A)(F=44.1$ and 27.6 for $S$ and $N$, respectively; $\mathrm{df}=3,16$; 

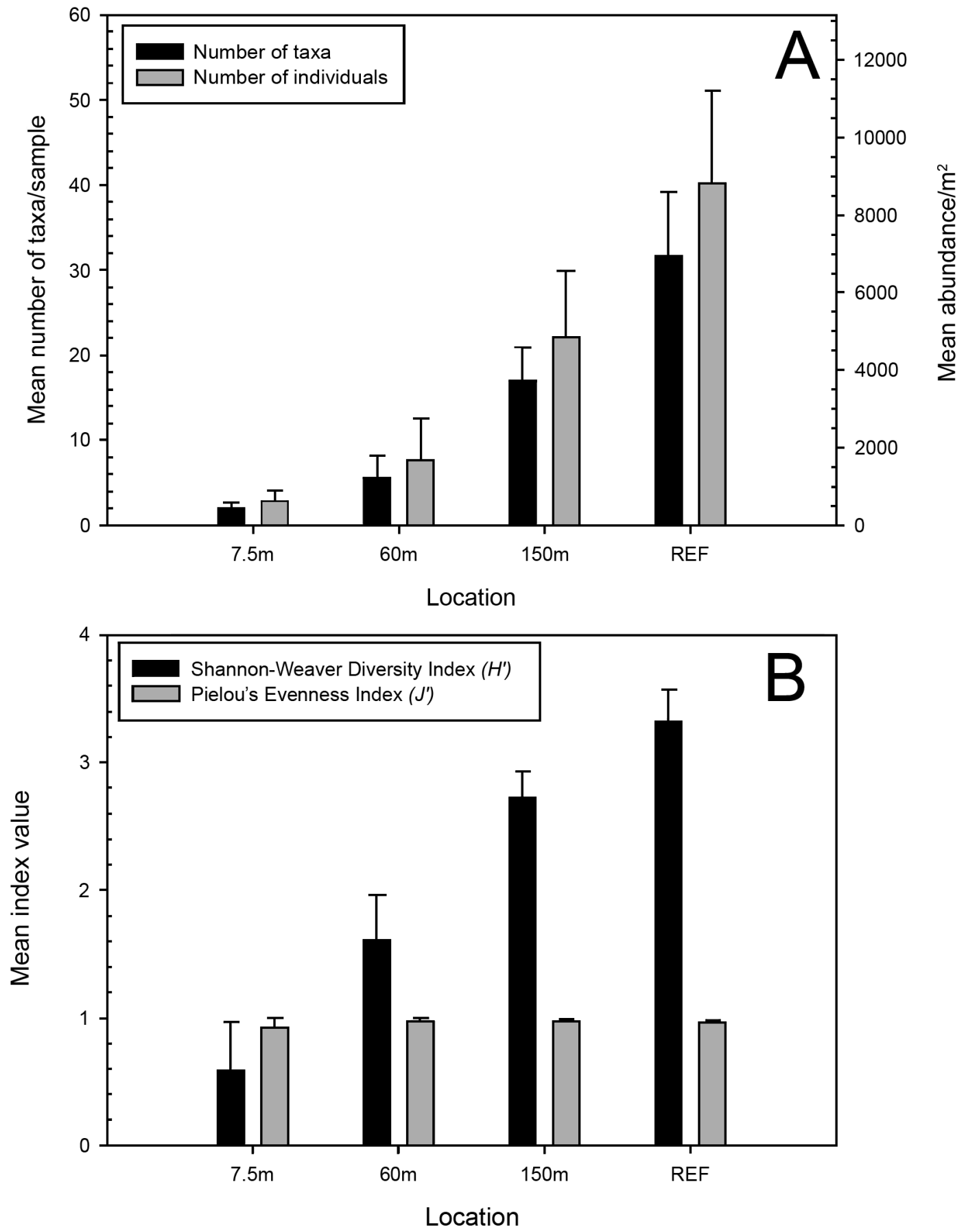

Figure 3. $(A)$ The mean number of taxa $(S)$ and abundance $(N)$ of benthic macrofauna per sample at the transect and reference sites. Error bar $=1$ standard deviation, sample area $=0.00456 \mathrm{~m}^{2}$. All pairwise comparisons between the reference (REF), $150 \mathrm{~m}$, and $60 \mathrm{~m}$ sites were significantly different for both $S$ and $N$. The $60 \mathrm{~m}$ and $7.5 \mathrm{~m}$ sites were not significantly different. $(B)$ Mean Shannon-Weaver Diversity $\left(H^{\prime}\right)$ and Pielou's Evenness $\left(\mathcal{f}^{\prime}\right)$ values at transect and reference sites. Error bar $=1$ standard deviation. All pairwise comparisons between sites were significantly different for $H^{\prime}$. There was no significant difference in $\mathcal{f}^{\prime}$ between sites. 

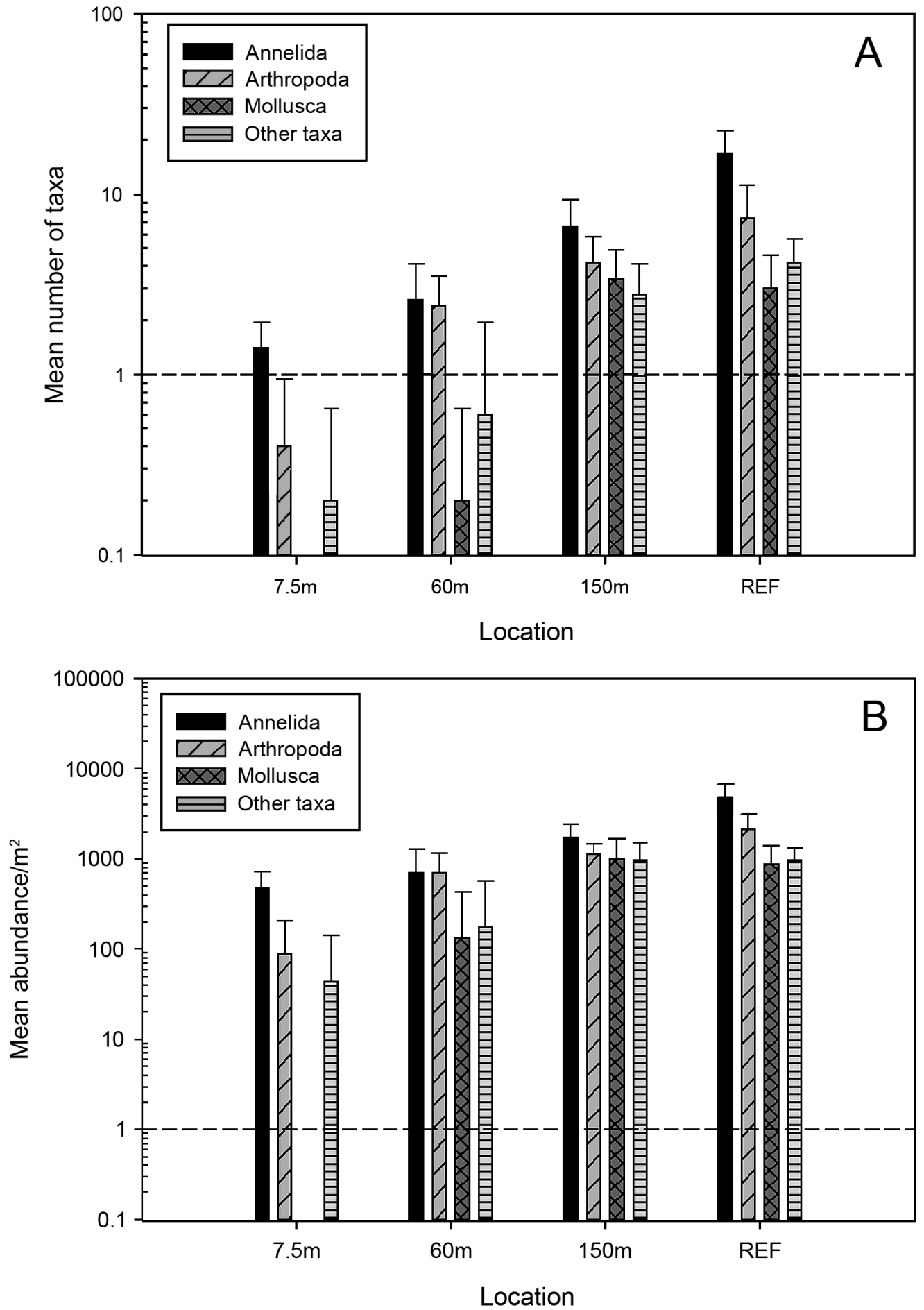

Figure 4. (A) Mean number of taxa by major taxonomic groups at transect and reference sites. $(B)$ Mean abundance of major taxonomic groups at transect and reference sites. 
$P<.001)$. The $150 \mathrm{~m}$ site also was significantly higher in both numbers of taxa and abundance than the other two transect sites; however there was no significant difference between the $7.5 \mathrm{~m}$ and the $60 \mathrm{~m}$ sites for either measure. The Shannon-Weaver Diversity index $\left(H^{\prime}\right)$ also showed an increasing trend with distance from the vents (Figure $3 B)$. All sites were significantly different from each other $(F=77.7$; df $=3,16 ; P<.001)$. There was no significant difference in evenness between sites $(H=0.766, \mathrm{df}=3, P=$ .86). Most taxa were represented by a single individual, resulting in high evenness values.

Annelids composed the largest percentage of taxa at all sites (Figure $4 A$ ) and were represented by 92 taxa overall, or $>50 \%$ of the taxa identified in this study. The $7.5 \mathrm{~m}$ site had only three annelid taxa, which represented half of the taxa found due to the low species richness at that site. The $60 \mathrm{~m}$ and $150 \mathrm{~m}$ sites had 10 and 24 annelid taxa, respectively, and the reference site had 60 annelid taxa. Annelids also were the most abundant invertebrates, comprising close to $50 \%$ of the overall abundance for all sites, followed by arthropods, which represented close to $25 \%$ of the total abundance overall (Figure $4 A$ and $B$ ). Mollusks were also prevalent at $150 \mathrm{~m}$ and at the reference site (12 and 11 taxa, respectively) but were absent at $7.5 \mathrm{~m}$ and were represented by only one species at $60 \mathrm{~m}$ (Figure $4 A$ and $B$ ).

Analysis of similarity (ANOSIM) indicated that the species composition was significantly different between sites (global $R=0.764$, $P=.001)$. The SIMPER analysis by distance (Table 4) showed that the five replicates from $7.5 \mathrm{~m}$ had an average similarity of $29 \%$ due to the presence of the polychaetes Malacoceros sp. A and Capitella cf. capitata, which accounted for $52 \%$ and $48 \%$ of the similarity, respectively. The $60 \mathrm{~m}$ replicates had an average similarity of $21 \%$, with the unidentified cumacean (designated as Cumacea sp. A) contributing $50 \%$ to the similarity. The $150 \mathrm{~m}$ samples had an average similarity of $26 \%$ mostly due to an unidentified sipunculan worm (sipunculan sp. B), an isopod (Paranthuridae? sp. A), and the polychaete Heteropodarke sp. A. The five replicates from the

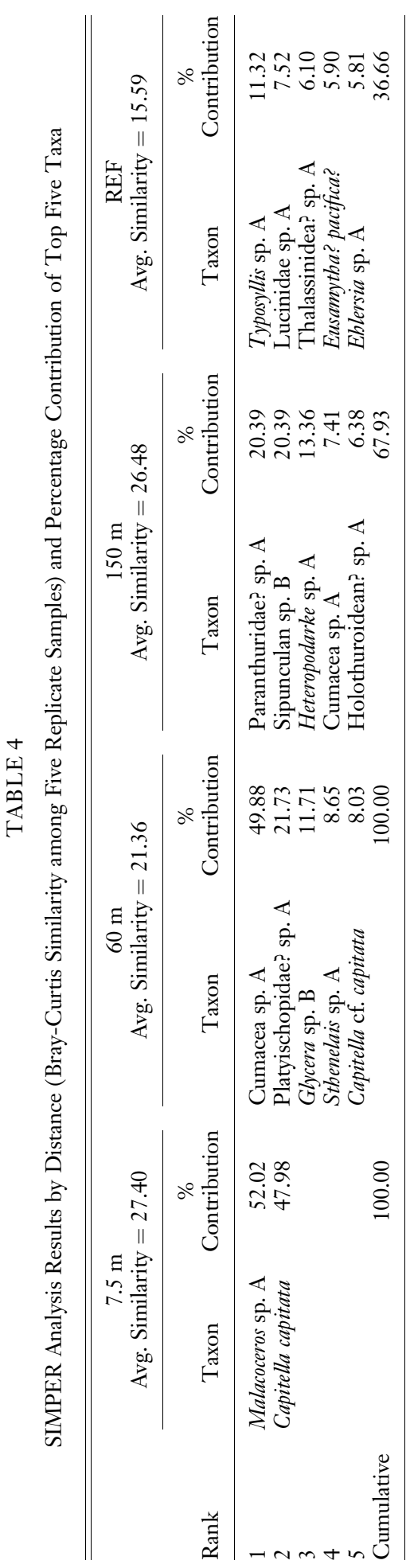




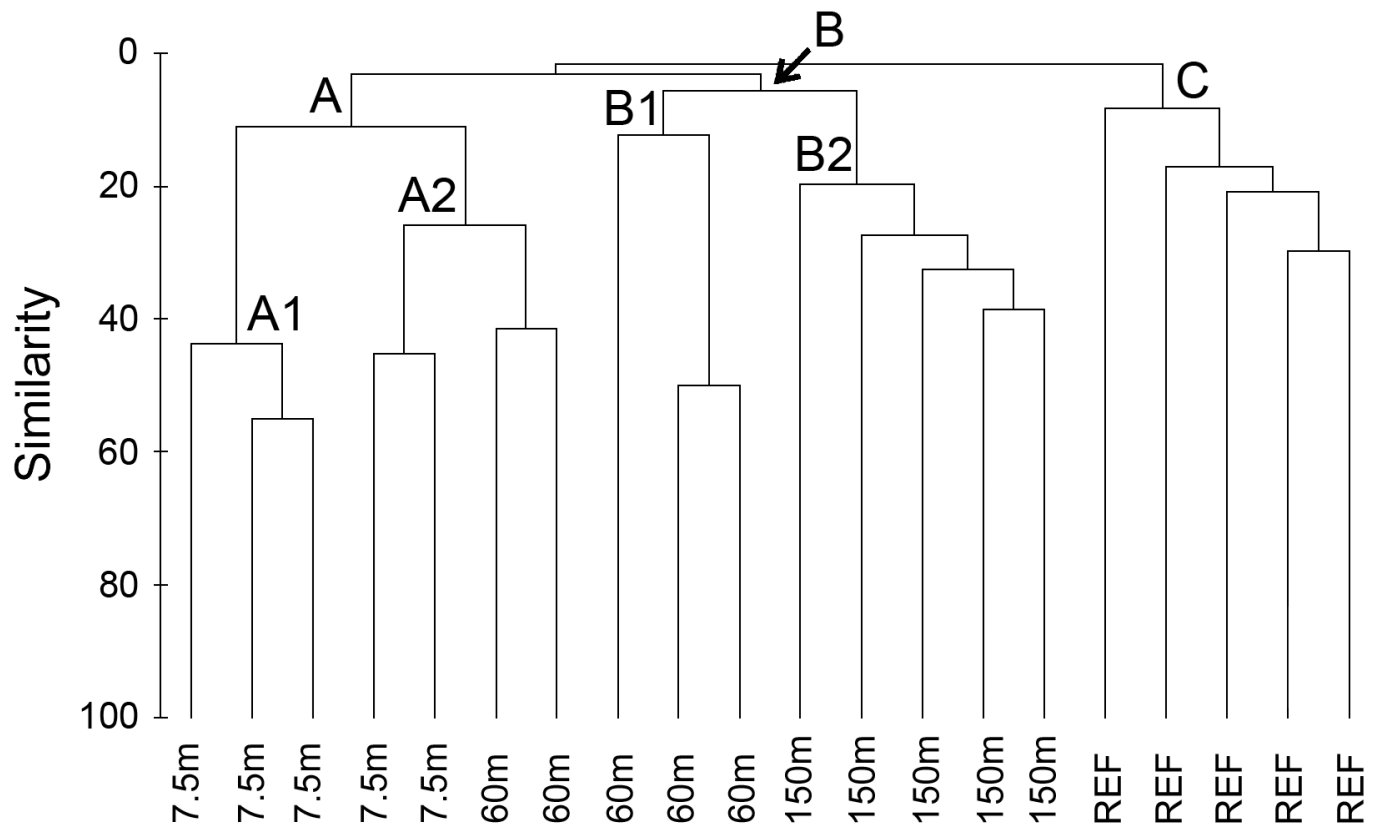

Location

Figure 5. Cluster analysis: Bray-Curtis Similarity based on square root transformed macrofaunal abundance data.

reference site had an average similarity of $15.6 \%$, with the polychaete Typosyllis sp. A accounting for $11 \%$ of the similarity between the samples.

The cluster analysis of abundance data showed the sites clustering in three main groups designated as A, B, and C (Figure 5). Group A consisted of all five replicates from $7.5 \mathrm{~m}$ along with two replicates from $60 \mathrm{~m}$. SIMPER analysis of the cluster groups showed that the Group A sites had an average similarity of $22 \%$, with the polychaete Capitella cf. capitata accounting for $64 \%$ of the similarity. Group A was divided into two subgroups: A1 and A2. The A1 subgroup consisted of three of the $7.5 \mathrm{~m}$ samples and had an average similarity of $48 \%$ due to the presence of the polychaete Malacoceros sp. A. The A2 subgroup was composed of two $7.5 \mathrm{~m}$ samples and two $60 \mathrm{~m}$ samples, with an average similarity of $32 \%$ due to the polychaete Capitella cf. capitata. Group B was composed of the remaining three $60 \mathrm{~m}$ samples and all five $150 \mathrm{~m}$ samples and had an average similarity of $15 \%$. The similarity among the group B samples was due to the abundance of Cumacea sp. A, which accounted for $33 \%$ of the similarity. Group B was divided into two subgroups: B1 and B2. The B1 subgroup included three replicates from $60 \mathrm{~m}$ and had an average similarity of $25 \%$ due to the presence of Cumacea sp. A. The B2 subgroup consisted of the five $150 \mathrm{~m}$ replicates and had an average similarity of $26.5 \%$ due to the isopod Paranthuridae? sp. A and the sipunculan sp. B. Group C consisted of the five reference-site samples and had an average similarity of $15.6 \%$ due in part to the polychaete Typosyllis sp. A.

The BIO-ENV analysis indicated that for single environmental variables, $\mathrm{pH}$ best explained the benthic species assemblage data [Spearman correlation (rho) $\rho=0.703$ ], followed by temperature $(\rho=0.682)$ (Table 5). The combination of $\mathrm{pH}$ and temperature with various sediment grain size classes re- 
TABLE 5

BIO-ENV Results for Single and Multiple Parameters

\begin{tabular}{|c|c|}
\hline Variable $^{a}$ & $\begin{array}{c}\text { Spearman Correlation } \\
\text { Coefficient }\left(\rho_{\mathrm{s}}\right)\end{array}$ \\
\hline \%CS; temperature; $\mathrm{pH}$ & 0.709 \\
\hline $\begin{array}{l}\% \mathrm{G} ; \% \mathrm{CS} ; \% \mathrm{FS} ; \\
\text { temperature; } \mathrm{pH}\end{array}$ & 0.709 \\
\hline $\begin{array}{l}\text { \% G; \%FS; sediment As; } \\
\text { temperature; } \mathrm{pH}\end{array}$ & 0.709 \\
\hline $\mathrm{pH}$ & 0.703 \\
\hline$\% \mathrm{CO}_{3} ;$ temperature; $\mathrm{pH}$ & 0.703 \\
\hline $\begin{array}{l}\% \mathrm{G} ; \% \mathrm{FS} ; \% \mathrm{CO}_{3} ; \\
\text { temperature; } \mathrm{pH}\end{array}$ & 0.703 \\
\hline Temperature & 0.682 \\
\hline$\%$ Silt + Clay & 0.603 \\
\hline$\% \mathrm{Fe}$ & 0.568 \\
\hline Sediment As & 0.568 \\
\hline Pore water As & 0.429 \\
\hline
\end{tabular}

a \%G, \% Gravel; \%CS, \% Coarse Sand; \%FS, \% Fine Sand; $\% \mathrm{CO}_{3}, \%$ carbonates; $\% \mathrm{Fe}, \%$ iron.

sulted in a slightly higher correlation $(\rho=$ 0.709) (Table 5). Conversely, the total arsenic concentration in the sediment and pore water showed relatively weaker correlations with the benthic macrofauna assemblage (Table 5) $(\rho=0.568$ and 0.429 , respectively).

\section{DISCUSSION}

Despite the small sample size and limited area sampled at each site, there was a statistically significant trend of increasing species richness, abundance, and diversity with distance from the vent out to $150 \mathrm{~m}$. These measures were still depressed relative to the reference site, suggesting that the hydrothermal system still influenced the infaunal structure as far away as $150 \mathrm{~m}$. The benthic macrofauna composition at the reference site showed little similarity to that at any of the transect sites as revealed by the cluster analysis (Figure 5). Among the three transect locations, the 7.5 and $150 \mathrm{~m}$ species assemblages showed little similarity to each other, and the benthic community at $60 \mathrm{~m}$ appeared to be transitional between the other two transect sites.

Several physical variables could be responsible for the observed trends in the benthic macrofauna assemblage, including tempera- ture, $\mathrm{pH}$, arsenic content, and sediment composition. Other factors such as currents, tides, wave action, and changes in the volume of vent flow could also affect the vent's influence on the infaunal community, but these variables were not observed in this study. There is a correlation between increasing $\mathrm{pH}$ and increasing presence of carbonates in the sediment. These changes in sediment composition and benthic infaunal abundance and diversity may be influenced by both geochemistry and bioturbation due to burrowing organisms (Aller 1982, Dhalgren et al. 1999, Widdicombe et al. 2000). Numerous active callianassid shrimp burrows were observed along the transect. In our core samples a single individual was found at $60 \mathrm{~m}$, two at $150 \mathrm{~m}$, and four at the reference site. However, callianassid shrimp are likely underrepresented in our samples due to the depth of their burrows. In addition, observations made during a night dive along the transect revealed high densities of sea pens (Octocorallia: Pennatulacea) starting approximately $100 \mathrm{~m}$ out from the vent in fine-grain volcanic sand. These apparently remain in deep burrows during the day and thus were not represented in our core samples. The change in macrofaunal composition along the transect is most strongly correlated with $\mathrm{pH}$ although temperature and grain size were also important, as shown in the BIO-ENV results (Table 5). Mollusks were completely absent at the $7.5 \mathrm{~m}$ site, a single opisthobranch gastropod (Cylichnidae, genus undet.) was found at the $60 \mathrm{~m}$ site, and the $150 \mathrm{~m}$ site contained 12 molluscan species or $22 \%$ of the species present at that site. The increased presence of shelled mollusks may be caused by the $\mathrm{pH}$ gradient along the transect because solid carbonates form less readily at low $\mathrm{pH}$ (Milliman 1974).

The apparent lack of molluscan fauna near the vent in this study differs from studies conducted at three other shallow hydrothermal systems (Kamenev et al. 1993, Thiermann et al. 1997, Kamenev et al. 2004), where mollusks were found in association with hydrothermal vents. Those sites were different from Ambitle Island in that hydrogen sulfide concentrations seemed to be an important 
factor influencing infaunal benthic communities. Those studies did not report $\mathrm{pH}$ values, so the association between $\mathrm{pH}$ and molluscan communities was not established. One recent study (Hall-Spencer et al. 2008) did show that reduced $\mathrm{pH}$ from the release of $\mathrm{CO}_{2}$ in a shallow volcanic vent caused reductions in the abundance of coralline algae and other calcareous organisms.

One species of note in this study is the capitellid polychaete Capitella cf. capitata, which was found at both the 7.5 and $60 \mathrm{~m}$ sites. This cosmopolitan taxon has long been recognized as a complex of several morphologically similar species and historically has been associated with degraded or disturbed habitats (Grassle and Grassle 1976). Thiermann et al. (1997) found a sibling species of Capitella capitata associated with the transition zone near a shallow-water hydrothermal vent in the Aegean Sea. This population was designated as Capitella sp. M and was characterized by its tolerance of high sulfide levels (Gamenick et al. 1998). High sulfide concentrations have not been associated with the Ambitle Island vents (Pichler et al. 1999b), but the $C$. capitata specimens found in this study were associated with high temperatures and high arsenic levels as well as low $\mathrm{pH}$.

Our results suggest that the infauna near the vents is represented by few taxa and low abundances and primarily consists of opportunistic taxa such as Capitella capitata. These taxa are most likely a subset of the surrounding benthic community rather than specialized organisms adapted to a chemosynthetic metabolism as found in deep-sea hydrothermal vents. A result similar to ours was found in shallow hydrothermal vent systems near southern California and the Gulf of California (Melwani and Kim 2008).

These results suggest that the arsenic from the vent fluids is effectively sequestered in the sediments, as found in earlier studies (Pichler et al. 1999a), and does not significantly influence either benthic community structure or the observed surrounding reef habitat. Instead, the reduced $\mathrm{pH}$ appears to affect the benthic species composition around the vent, which is evidenced by the absence of mollusks near the vent, the reduced molluscan fauna at $60 \mathrm{~m}$, and the absence of carbonate sediments at both of those sites. The influence of $\mathrm{pH}$ on the benthic community structure is further supported by the BIO-ENV analysis results. This finding further supports the results found at a similar site in the Mediterranean Sea (Hall-Spencer et al. 2008) that showed that reduced $\mathrm{pH}$ due to the venting of $\mathrm{CO}_{2}$ at shallow-water volcanic vents affected the abundance of calcareous organisms in the surrounding benthic community.

This study of the Ambitle Island vent system demonstrates that the effects of a small, shallow hydrothermal vent can extend much farther from the point source than previous studies have shown, presumably due to the effects of diffuse venting of $\mathrm{CO}_{2}$ gas and hydrothermal fluids in the surrounding sediments. We found effects as far as $150 \mathrm{~m}$ from the vent, suggesting that future studies at shallow hydrothermal vents incorporate much longer transects.

\section{ACKNOWLEDGMENTS}

We thank Pamela Hallock-Muller, Brian McCloskey, Jan Amend, and Darcy MeyerDombard for their field assistance. We also thank the crew of the M/V Star Dancer and the government of Papua New Guinea.

\section{Literature Cited}

Aller, R. C. 1982. Carbonate dissolution in nearshore terrigenous muds: The role of physical and biological reworking. J. Geol. 90:79-95.

Andreae, M. O. 1979. Arsenic speciation in seawater and interstitial waters: The influence of biological-chemical interactions on the chemistry of a trace element. Limnol. Oceanogr. 24:440-452.

Barwick, M., and W. Maher. 2003. Biotransference and biomagnification of selenium, copper, cadmium, zinc, arsenic and lead in a temperate seagrass ecosystem from Lake Macquarie Estuary, NSW, Australia. Mar. Environ. Res. 56:471-502.

Burdige, D. J., and R. C. Zimmerman. 2002. Impact of sea grass density on carbonate 
dissolution in Bahamian sediments. Limnol. Oceanogr. 47:1751-1763.

Clarke, K. R., and M. Ainsworth. 1993. A method of linking multivariate community structure to environmental variables. Mar. Ecol. Prog. Ser. 92:205-219.

Clarke, K. R., and R. N. Gorley. 2006. PRIMER v. 6: User manual/tutorial. PRIMER-E, Plymouth, United Kingdom.

Cocito, S., C. N. Bianchi, C. Morri, and A. Peirano. 2000. First survey of sessile communities on subtidal rocks in an area with hydrothermal vents: Milos Island, Aegean Sea. Hydrobiologia 426:113-121.

Cutter, G. A., L. S. Cutter, A. M. Featherstone, and S. E. Lohrenz. 2001. Antimony and arsenic biogeochemistry in the western Atlantic Ocean. Deep Sea Res. Part II Top. Stud. Oceanogr. 48:2895-2915.

Dhalgren, C. P., M. H. Posey, and A. W. Hulbert. 1999. The effects of bioturbation on the infaunal community adjacent to an offshore hardbottom reef. Bull. Mar. Sci. 64:21-34.

Francesconi, K. A., and D. Kuehnelt. 2002. Arsenic compounds in the environment. Pages 51-94 in W. T. Frankenberger Jr., ed. Environmental chemistry of arsenic. Marcel Dekker, Inc., New York.

Gamenick, I., M. Abbiati, and O. Giere. 1998. Field distribution and sulphide tolerance of Capitella capitata (Annelida: Polychaeta) around shallow water hydrothermal vents off Milos (Aegean Sea): A new sibling species? Mar. Biol. (Berl.) 130:447-453.

Grassle, J. P., and J. F. Grassle. 1976. Sibling species in the marine pollution indicator Capitella (Polychaeta). Science (Washington, D.C.) 192:567-569.

Green, M. A., R. C. Aller, and J. Y. Aller. 1993. Carbonate dissolution and temporal abundances of Foraminifera in Long Island Sound sediments. Limnol. Oceanogr. 38:331-345.

Hall-Spencer, J. M., R. Rodolfo-Metalpa, S. Martin, E. Ransome, M. Fine, S. M. Turner, S. J. Rowley, D. Tedesco, and M.-C. Buia. 2008. Volcanic carbon dioxide vents show ecosystem effects of ocean acidification. Nature (Lond.) 454:96-99.
Heiri, O., A. F. Lotter, and G. Lemcke. 2001. Loss on ignition as a method for estimating organic and carbonate content in sediments: Reproducibility and comparability of results. J. Paleolimnol. 25:101-110.

Inskeep, W. P., T. R. McDermott, and S. Fendorf. 2002. Arsenic (V)/(III) cycling in soils and natural waters: Chemical and microbiological processes. Pages 183-215 in W. T. Frankenberger Jr., ed. Environmental chemistry of arsenic. Marcel Dekker, Inc., New York.

Kamenev, G. M., V. I. Fadeev, N. I. Selin, V. G. Tarasov, and V. V. Malakhov. 1993. Composition and distribution of macro- and meiobenthos around sublittoral hydrothermal vents in the Bay of Plenty, New Zealand. N. Z. J. Mar. Freshwater Res. 27:407-418.

Kamenev, G. M., V. Ya. Kavun, V. G. Tarasov, and V. I. Fadeev. 2004. Distribution of bivalve mollusks Macoma golikovi Scarlato and Kafanov, 1998 and Macoma calcarea (Gmelin, 1791) in the shallow-water hydrothermal ecosystem of Kraternaya Bight (Yankich Island, Kuril Islands): Connection with feeding type and hydrothermal activity of Ushishir Volcano. Cont. Shelf Res. 24:75-95.

Kitts, H. J., G. E. Millward, A. W. Morris, and L. Ebdon. 1994. Arsenic biogeochemistry in the Humber Estuary, U.K. Estuarine Coastal Shelf Sci. 39:157-172.

Melwani, A. R., and S. L. Kim. 2008. Benthic infaunal distributions in shallow hydrothermal vent sediments. Acta Oecol. 33:162-175.

Milliman, J. D. 1974. Marine carbonates. Springer Verlag, Berlin.

Morri, C., C. N. Bianchi, S. Cocito, A. Peirano, A. M. De Biase, S. Aliani, M. Pansini, M. Boyer, F. Ferdeghini, M. Pestarino, and P. Dando. 1999. Biodiversity of marine sessile epifauna at an Aegean island subject to hydrothermal activity: Milos, eastern Mediterranean Sea. Mar. Biol. (Berl.) 135:729-739.

Oremland, R. S., T. R. Kulp, J. Switzer Blum, S. E. Hoeft, S. Baesman, L. G. Miller, and J. F. Stolz. 2005. A microbial arsenic cycle in a salt-saturated extreme environment. 
Science (Washington, D.C.) 308:13051308.

Oremland, R. S., and J. F. Stolz. 2003. The ecology of arsenic. Science (Washington, D.C.) 300:939-944.

Percival, J. B., and P. J. Lindsay. 1997. Measurement of physical properties of sediments. Pages 7-45 in A. Mudroch, J. M. Azcue, and P. Mudroch, eds., Manual of physico-chemical analysis of aquatic sediments. CRC Press, Boca Raton, Florida.

Pichler, T., and G. R. Dix. 1996. Hydrothermal venting within a coral reef ecosystem, Ambitle Island, Papua New Guinea. Geology 20:435-438.

Pichler, T., and J. Veizer. 1999. Precipitation of $\mathrm{Fe}$ (III) oxyhydroxide deposits from shallow-water hydrothermal fluids in $\mathrm{Tu}-$ tum Bay, Ambitle Island, Papua New Guinea. Chem. Geol. 162:15-31.

Pichler, T., J. Veizer, and G. E. M. Hall. 1999a. Natural input of arsenic into a coral-reef ecosystem by hydrothermal fluids and its removal by Fe (III) oxyhydroxides. Environ. Sci. Technol. 33:13731378.

1999b. The chemical composition of shallow-water hydrothermal fluids in Tutum Bay, Ambitle Island, Papua New Guinea and their effect on ambient seawater. Mar. Chem. 64:229-252.

Price, R. E., and T. Pichler. 2005. Distribution, speciation and bioavailability of arsenic in a shallow-water submarine hydrothermal system, Tutum Bay, Ambitle Island, PNG. Chem. Geol. 224:122-135.

Rohlf, F. J., and R. R. Sokal. 1981. Statistical tables. Freeman and Company, New York.

Sanders, H. L. 1958. Benthic studies in Buzzards Bay. I. Animal-sediment relationships. Limnol. Oceanogr. 3:245-258.

Snelgrove, P. V. R., and C. A. Butman. 1994.
Animal sediment relationships revisitedcause versus effect. Oceanogr. Mar. Biol. 32:111-177.

Sorokin, Yu. I., P. Yu. Sorokin, and O. Yu. Zakouskina. 2003. Microplankton and its function in a zone of shallow hydrothermal activity: The Craternaya Bay, Kurile Islands. J. Plankton Res. 25:495-506.

Systat Software. 2005. SigmaStat 3.5. Systat Software, Inc., Richmond, California.

Tarasov, V. G., A. V. Gebruk, V. M. Shulkin, G. M. Kamenev, V. I. Fadeev, V. N. Kosmynin, V. V. Malakhov, D. A. Starynin, and A. I. Obshirov. 1999. Effect of shallow-water hydrothermal venting on the biota of Matupi Harbour (Rabaul Caldera, New Britain Island, Papua New Guinea). Cont. Shelf Res. 19:79-116.

Tarasov, V. G., M. V. Propp, L. N. Propp, A. V. Zhirmunsky, B. B. Namsaraev, V. M. Gorlenko, and D. A. Starynin. 1990. Shallow-water gasohydrothermal vents of Ushishir Volcano and the ecosystem of Kraternaya Bight (the Kurile Islands). Mar. Ecol. 11:1-23.

Thiermann, F., I. Akoumianaki, J. A. Hughes, and O. Giere. 1997. Benthic fauna of a shallow-water gaseohydrothermal vent area in the Aegean Sea (Milos, Greece). Mar. Biol. (Berl.) 128:149-159.

Watt, C., and X. E. Le. 2003. Arsenic speciation in natural waters. Pages 11-32 in Y. Cai and O. C. Braids, eds. Biogeochemistry of environmentally important trace elements. ACS (Am. Chem. Soc.) Symp. Ser. 835.

Widdicombe, S., M. C. Austen, M. A. Kendall, R. M. Warwick, and M. B. Jones. 2000. Bioturbation as a mechanism for setting and maintaining levels of diversity in subtidal macrobenthic communities. Hydrobiologia 440:369-377. 